\title{
Analisa Tingkat Pelayanan Jalan Raya Kalirungkut dengan Adanya Kegiatan Pusat Perbelanjaan Transmart Rungkut, Kota Surabaya
}

\author{
Alfian Haris Aryawan dan Sardjito \\ Departemen Perencanaan Wilayah dan Kota, Fakultas Arsitektur Desain dan Perencanaan \\ Institut Teknologi Sepuluh Nopember (ITS) \\ e-mail: sardjito24@yahoo.com
}

\begin{abstract}
Abstrak - Eratnya kaitan tata guna lahan dan transportasi memberikan berbagai dampak tersendiri baik dari segi sistem transportasi maupun sistem tata guna lahan. salah satunya adalah kegiatan perdagangan dan jasa terhadap jalan. Carefour merupakan salah satu supermarket yang pernah ada disisi jalan Raya Kalirungkut telah berubah menjadi Transmart Rungkut yang merupakan supermarket terintegrasi dengan kuliner serta rekreasi dan beberapa jenis penawaran perdagangan dan jasa yang jarang ditemukan pada supermarket pada umumnya. Pasca beroperasi (2017), Transmart Rungkut memberikan dampak berupa hambatan pergerakan terhadap kegiatan lalu lintas Jalan Raya Kalirungkut. Penelitian ini dilaksanakan untuk mengetahui besar pengaruh kegiatan pusat perbelanjaan Transmart Rungkut terhadap kinerja Jalan Raya Kalirungkut Kota Surabaya. Tujuan dari penelitian ini adalah untuk menghitung tingkat pelayanan Jalan Raya Kalirungkut Kota Surabaya. Alat analisis yang digunakan untuk mencapai sasaran ini adalah analisis Tingkat Pelayanan Jalan yang dimuat dalam MKJI (1997).
\end{abstract}

Kata Kunci-Tingkat Pelayanan Jalan, Pusat Perbelanjaan.

\section{PENDAHULUAN}

$\mathrm{S}_{\mathrm{p}}^{\mathrm{IS}}$ ISTEM transportasi selalu erat kaitannya dengan sistem pergerakan dan sistem kegiatan. Dalam suatu kawasan tertentu, sistem transportasi mempunyai hubungan erat dengan sistem aktivitas sosial ekonomi manusia [1]. Sistem transportasi juga diartikan sebagai suatu kesatuan daripada elemen-elemen, komponen-komponen yang saling mendukung dan bekerja sama dalam pengadaan transportasi yang melayani wilayah perkotaan [1]. Sistem transportasi secara menyeluruh (makro) dapat dipecahkan menjadi beberapa sistem yang lebih kecil (mikro) yang masing-masing saling terkait dan saling mempengaruhi. Sistem transportasi perkotaan terdiri atas berbagai aktivitas seperti bekerja, sekolah, olahraga, belanja, dan bertamu yang berlangsung diatas sebidang tanah (kantor, pabrik, pertokoan, rumah, dan lain-lain) [2]. Kegiatan pada suatu bidang tanah tersebut dinamakan tata guna lahan. berdasarkan pengertian tersebut, sistem transportasi sangat erat kaitannya dengan aktivitas disuatu tata guna lahan. setiap tata guna lahan atau sistem kegiatan yang mempunyai jenis kegiatan tertentu yang akan membangkitkan dan menarik pergerakan dalam proses pemenuhan kebutuhan [2]. Akibat dari keterkaitan tersebut, terbentuk lah pola pergerakan yang dikelompokkan berdasarkan pergerakan arus lalu-lintas asaltujuan [1], sebagai berikut: Pergerakan internal-internal; pergerakan internal-eksternal; pergerakan eksternal-internal; serta pergerakan eksternal-eksternal.

Berdasarkan RTRW Kota Surabaya Tahun 2011, Kota Surabaya merupakan kota yang dikategorikan sebagai kawasan PKN (Pusat Kegiatan Nasional). Akibat dari hal tersebut, pergerakan dikawasan Kota Surabaya terus meningkat akibat dari orang dan barang yang perlu berpindah dari satu tempat ke tempat yang lain dalam memenuhi kebutuhannya, dan hal tersebut memberikan dampak pada volume kendaraan yang terus meningkat akibat distribusi penggunaan transportasi yang tidak hanya berasal dari dalam kota sendiri melainkan luar kota juga ikut mempengaruhi.

UP I Rungkut merupakan salah satu Unit Pengembangan kawasan di wilayah timur Kota Surabaya dengan fungsi utama sebagai permukiman, perdagangan dan jasa, pendidikan, lindung terhadap alam dan industri. Dengan fungsi utama unit pengembangan yang beraneka ragam, proses mobilitas kawasan Unit Pengembanga Rungkut tergolong cukup tinggi. Kegiatan industri yang dipusatkan pada UP I Rungkut yaitu SIER (Surabaya Industrial Estate Rungkut) berakibat pada terciptanya daya tarik tersendiri dalam pemenuhan kebutuhan perindustrian di kawasan Kota Surabaya yang memiliki tingkat pelayanan skala nasional. Salah satu jalan yang mendukung mobilitas kegiatan dari fungsi utama Unit Pengembangan I Rungkut adalah Jalan Raya Kaliungkut.

Jalan Raya Kalirungkut merupakan jalan dengan fungsi sebagai jalan arteri sekunder. Jalan Raya Kalirungkut merupakan salah satu jalan yang memiliki fungsi dalam mendukung pemenuhan kebutuhan terhadap Kota Surabaya, kota-kota yang berada di sekitar Kota Surabaya, bahkan lebih jauh daripada itu. Namun dengan fungsi jalan yang memiliki fungsi pendukung mobilitas antar perkotaan, beberapa titik di Jalan Raya Kalirungkut masih terdapat hambatan-hambatan perdagangan dan jasa di sisi kiri maupun kanan jalan salah satunya Pusat Perbelanjaan transmart Rungkut Kota Surabaya.

Pusat perbelanjaan Transmart Rungkut Kota Surabaya merupakan salah satu bentuk persebaran kegiatan perdagangan dan jasa dalam bentuk pasar modern. Pasar modern memiliki sifat pertumbuhan yang linear disepanjang jalan. Akibat dari terbangunnya pusat perbelanjaan Transmart Rungkut Kota Surabaya Kegiatan perdagangan dan jasa yang cukup bervariasi dalam satu bangunan menyebabkan Pusat Perbelanjaan Transmart Rungkut Kota Surabaya menjadi bangunan dengan tarikan pergerakan. Selain kegiatan pusat perdagangan dan jasa yang cukup bervariasi, Pusat Perbelanjaan Transmart Rungkut 
Kota Surabaya merupakan Pusat Perbelanjaan yang juga menawarkan wahana bermain sekaligus. Akibat dari variasi perdagangan dan jasa serta adanya wahana bermain tersebut sirkulasi tarikan pergerakan orang maupun barang di Pusat Perbelanjaan Transmart Rungkut Kota Surabaya tergolong cukup tinggi.

Dari beberapa gambaran yang telah diberikan diatas, kondisi Jalan Raya Kalirungkut memiliki kondisi lalu lintas tergolong ramai. Pergerakan kawasan yang cukup tinggi dikarenakan fungsi utama Unit Pengembangan yang mencakup permukiman, perdagangan dan jasa, pendidikan, lindung terhadap alam dan industri menyebabkan meningkatnya kepadatan lalu-lintas. Selain itu, menumpuknya kendaraan di salah satu lajur jalan baik untuk memasuki area pusat perbelanjaan maupun menurunkan penumpang yang memiliki tujuan pusat perbelanjaan Transmart Rungkut menyebabkan bertambahnya volume lalu lintas. Oleh karena itu, penelitian ini dilakukan untuk mengukur tingkat pelayanan jalan Raya Rungkut akibat dari kegiatan perdagangan dan jasa pusat perbelanjaan Transmart Rungkut Kota Surabaya.

\section{METODE PENELITIAN}

\section{A. Jenis dan Pendekatan Penelitian}

Pendekatan yang digunakan dalam penelitian ini adalah pendekatan positivisme [3]. Jenis penelitian dalam penelitian ini adalah deskripti kuantitatif.

\section{B. Variabel Penelitian}

Variabel penelitian yang digunakan untuk mengukur tingkat pelayanan jalan Raya Rungkut akibat dari kegiatan perdagangan dan jasa pusat perbelanjaan Transmart Rungkut Kota Surabaya antara lain kapasitas jalan dengan sub-variabel lebar efektif jalan, hambatan samping, pembagian lajur, pembagian arah lajur, dan ukuran kota; kemudian variabel volume lalu lintas dengan sub-variabel jenis kendaraan dan jumlah kendaraan.

\section{Menghitung Tingkat Pelayanan Jalan Raya Kalirungkut Kota Surabaya}

Tingkat pelayanan jalan adalah suatu ukuran kualitatif yang menjelaskan kondisi-kondisi operasional di dalam suatu aliran lalu lintas dan persepsi dari pengemudi atau penumpang terhadap kondisi-kondisi tersebut [4].

Penilaian tingkat pelayanan jalan berdasarkan dua faktor yaitu:

- Kecepatan perjalanan

- Perbandingan volume dan kapasitas jalan yang menunjukkan kepadatan lalu lintas.

Setiap fasilitas dapat dievaluasi berdasarkan enam tingkat pelayanan, A sampai F, dimana A mempresentasikan kondisi operasional terbaik dan $\mathrm{F}$ untuk kondisi terburuk [4]. Karakteristik penilaian pelayanan jalan utama dan sub urban berdasarkan rasio adalah:

Dimana:

$$
I=\frac{V}{C}
$$

I = Derajat Kejenuhan

$\mathrm{V}=$ Volume arus total

$\mathrm{C}=$ Kapasitas

\section{HASIL DAN DISKUSI}

\section{A. Menghitung Tingkat Pelayanan Jalan Raya Kalirungkut Kota Surabaya}

Dalam analisis terkait Kinerja jalan, perlu diketahui kapasitas dan volume lalu lintas jalan yang menjadi fokusan dalam penelitian. Dalam perhitungan kapasitas jalan perlu diketahui geometrik dari jalan yang menjadi fokusan penelitian, sedangkan untuk mengetahui volume lalu lintas jalan yang menjadi fokusan penelitian perlu diketahui jumlah kendaraan yang melintas (smp) per satuan waktu.

\section{Kapasitas Jalan}

Perhitungan Kapasitas Jalan seperti yang sudah disebutkan di atas bahwa perhitungan memerlukan pertimbangan kondisi geometrik jalan itu sendiri. Geometrik Jalan pada wilayah penelitian dapat diketahui melalui pengilustrasian geometrik jalan dapat dilihat pada Gambar 1:

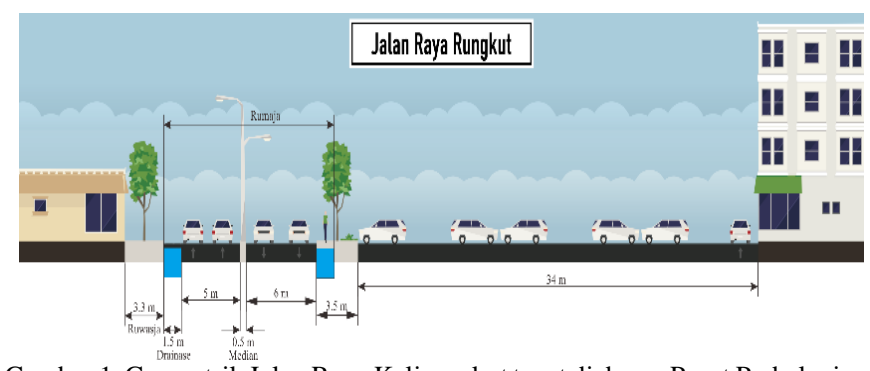

Gambar 1. Geometrik Jalan Raya Kalirungkut tepat di depan Pusat Perbelanjaan Transmart Rungkut Kota Surabaya (Sumber: Survey Primer, 2018)

Selain itu, persamaan umum untuk menghitung kapasitas suatu ruas jalan menurut metode Indonesian Highway Capacity Manual (IHCM, 1997) untuk daerah perkotaan adalah sebagai berikut:

$\mathrm{C}=\mathrm{C}_{0} \times \mathrm{FC}_{\mathrm{W}} \times \mathrm{FC}_{\mathrm{SP}} \times \mathrm{FC}_{\mathrm{SF}} \times \mathrm{FC}_{\mathrm{CS}}(\mathrm{smp} / \mathrm{jam})(1)$

Keterangan:

C : kapasitas (smp/jam)

$\mathrm{C}_{0} \quad$ : kapasitas dasar (smp/jam)

$\mathrm{FC}_{\mathrm{W}}$ : faktor koreksi kapasitas untuk lebar jalan

FC $_{\text {SP }}$ : faktor koreksi kapasitas akibat pembagian arah (tidak berlaku untuk jalan satu arah)

$\mathrm{FC}_{\mathrm{SF}} \quad$ : faktor koreksi kapasitas akibat gangguan samping

Perhitungan kapasitas Jalan Raya Kalirungkut berdasarkan variabel-variabel dalam rumus persamaan kapasitas jalan (C):

a. Faktor penyesuaian kapasitas dasar $\left(\mathrm{C}_{0}\right)$

Tabel 1.

Kapasitas Dasar $\left(\mathrm{C}_{0}\right)$

\begin{tabular}{lll}
\hline \hline Tipe Jalan & Kapasitas Dasar & Catatan \\
\hline $\begin{array}{l}\text { Empat lajur terbagi } \\
\text { atau jalan satu arah }\end{array}$ & 1650 & Perlajur \\
$\begin{array}{l}\text { Empat lajur tak } \\
\text { terbagi }\end{array}$ & 1500 & Perlajur \\
Dua lajur tak terbagi & 2900 & Total dua arah \\
\hline \hline
\end{tabular}

Sumber: IHCM (1997)

Tipe jalan dari Jalan Raya Kalirungkut adalah empat (4) lajur terbagi oleh median jalan dua (2) arah. Maka, nilai kapasitas dasar $\left(\mathrm{C}_{0}\right)$ adalah $1650 \times 2=3300$

$\mathrm{C}_{\mathbf{0}}=\mathbf{3 3 0 0}$

b. Faktor koreksi kapasitas akibat lebar jalan $\left(\mathrm{FC}_{\mathrm{w}}\right)$ 
Tabel 2.

Faktor Koreksi Kapasitas Akibat Lebar Jalan $\left(\mathrm{FC}_{\mathrm{w}}\right)$

\begin{tabular}{lcc}
\hline \hline Tipe Jalan & $\begin{array}{c}\text { Lebar lalu lintas jalan } \\
\text { efektif }\left(\mathrm{W}_{0}\right)(\mathrm{m})\end{array}$ & $\mathrm{FC}_{\mathrm{w}}$ \\
\hline Empat lajur & Perlajur & \\
terbagi atau & 3,00 & 0,92 \\
jalan satu arah & 3,25 & 0,96 \\
& 3,50 & 1,00 \\
& 3,75 & 1,04 \\
Empat lajur tak & 4,00 & 1,08 \\
terbagi & Perlajur & \\
& 3,00 & 0,91 \\
& 3,25 & 0,95 \\
& 3,50 & 1,00 \\
Dua lajur tak & 3,75 & 1,05 \\
terbagi & 4,00 & 1,09 \\
& Total dua arah & \\
& 5 & 0,56 \\
& 6 & 0,87 \\
& 7 & 1,00 \\
& 8 & 1,14 \\
& 9 & 1,25 \\
& 10 & 1,29 \\
\hline \hline
\end{tabular}

Sumber: IHCM (1997)

Tipe jalan dari Jalan Raya Kalirungkut adalah empat (4) lajur dua (2) arah dengan lebar efektif per lajurnya adalah 3 meter. Dengan demikian, dapat diketahui bahwa nilai Faktor Koreksi Kapasitas Akibat Lebar Jalan $\left(\mathrm{FC}_{\mathrm{W}}\right)$ adalah 0,92

$\mathrm{FCW}_{\mathbf{w}}=0,92$

c. Faktor penyesuaian kapasitas akibat pembagian arah $\left(\mathrm{FC}_{\mathrm{SP}}\right)$

Tabel 3.

Faktor penyesuaian kapasitas akibat pembagian arah $\left(\mathrm{FC}_{\mathrm{SP}}\right)$

\begin{tabular}{|c|c|c|c|c|c|c|c|}
\hline \multirow{3}{*}{\multicolumn{2}{|c|}{$\begin{array}{l}\text { Pemisahan arah } \\
\text { SP (\%-\%) }\end{array}$}} & 50 & 60 & 70 & 80 & 90 & 100 \\
\hline & & - & - & - & - & - & - \\
\hline & & 50 & 40 & 30 & 20 & 100 & 0 \\
\hline \multirow[t]{2}{*}{$\mathrm{FC}_{\mathrm{sp}}$} & $\begin{array}{l}\text { Dua lajur } \\
2 / 2\end{array}$ & 1,00 & 0,94 & 0,88 & 0,82 & 0,70 & 0,76 \\
\hline & $\begin{array}{l}\text { Empat } \\
\text { lajur 4/2 }\end{array}$ & 1,00 & 0,97 & 0,94 & 0,91 & 0,85 & 0,88 \\
\hline
\end{tabular}

Tipe jalan dari Jalan Raya Kalirungkut adalah empat (4) lajur dua (2) arah. Sehubung dengan penelitian yang hanya terfokus pada satu arah, maka pembagian arah SP adalah $50 \%-50 \%$, sehingga nilai faktor penyesuaian kapasitas akibat pembagian arah $\left(\mathrm{FC}_{\mathrm{SP}}\right)$ Jalan Raya Kalirungkut adalah 1,00 .

$\mathrm{FC}_{\text {SP }}=\mathbf{1 , 0 0}$

d. Faktor koreksi kapasitas akibat gangguan samping $\left(\mathrm{FC}_{\mathrm{SF}}\right)$

Tipe jalan dari Jalan Raya Kalirungkut adalah empat (4) lajur dua (2) arah dengan lebar efektif per lajurnya adalah 3 meter. Berdasarkan klasifikasi hambatan samping, Jalan Raya Kaliungkut termasuk pada kategori sedang dikarenakan kondisi tipikal kawasannya adalah daerah industri dengan beberapa toko di pinggir jalan, namun kondisi tipikal pada bagian jalan Raya Kalirungkut yang merupakan akses keluar-masuk dari pusat perbelanjaan Transmart Rungkut merupakan Daerah Komersial dengan aktivitas pinggir jalan yang tergolong tinggi. Berdasarkan kondisi tipikal tersebut, maka kelas gangguan sampig dari bagian jalan dari Jalan Raya Kalirungkut yang merupakan akses utama keluar-masuk pusat perbelanjaan Transmart Rungkut adalah Tinggi. Dijelaskan oleh Tabel 4 klasifikasi kelas hambatan samping:

Tabel 4.

Klasifikasi Kelas Hambatan Samping

\begin{tabular}{|c|c|c|}
\hline $\begin{array}{c}\text { Kelas } \\
\text { gangguan } \\
\text { samping }\end{array}$ & $\begin{array}{l}\text { Jumlah gangguan per } \\
200 \text { meter per jam } \\
\text { (dua arah) }\end{array}$ & Kondisi tipikal \\
\hline Sangat rendah & $<100$ & Permukiman \\
\hline Rendah & $100-299$ & $\begin{array}{l}\text { Permukiman, beberapa } \\
\text { transportasi umum }\end{array}$ \\
\hline Sedang & $300-499$ & $\begin{array}{l}\text { Daerah industri dengan } \\
\text { beberapa toko di } \\
\text { pinggir jalan }\end{array}$ \\
\hline Tinggi & $500-899$ & $\begin{array}{l}\text { Daerah komersial, } \\
\text { aktivitas pinggir jalan } \\
\text { tinggi }\end{array}$ \\
\hline Sangat tinggi & $>900$ & $\begin{array}{lr}\text { Daerah } & \text { komersial } \\
\text { dengan } & \text { aktivitas } \\
\text { perbelanjaan } & \text { pinggir } \\
\text { jalan } & \end{array}$ \\
\hline
\end{tabular}

Tabel 5.

Faktor Koreksi Kapasitas Akibat Gangguan Samping $\mathrm{FC}_{\mathrm{SF}}$ Untuk Jalan Yang Mempunyai Bahu Jalan

\begin{tabular}{|c|c|c|c|c|c|}
\hline \multirow{3}{*}{$\begin{array}{l}\text { Tipe } \\
\text { Jalan }\end{array}$} & \multirow{3}{*}{$\begin{array}{l}\text { Kelas Gangguar } \\
\text { Samping }\end{array}$} & \multicolumn{4}{|c|}{$\begin{array}{c}\text { Faktor Koreksi Akibat Gangguan } \\
\text { Samping dan Jarak Gangguan Pada } \\
\text { Kereb }\end{array}$} \\
\hline & & \multicolumn{4}{|c|}{ Lebar Kereb } \\
\hline & & $\leq 0,5$ & 1,0 & 1,5 & $\geq 2,0$ \\
\hline \multirow[t]{5}{*}{$4 / 2 \mathrm{D}$} & $\mathrm{VL}$ & 0,96 & 0,98 & 1,01 & 1,03 \\
\hline & $\mathrm{L}$ & 0,94 & 0,97 & 1,00 & 1,02 \\
\hline & M & 0,92 & 0,95 & 0,98 & 1,00 \\
\hline & $\mathrm{H}$ & 0,88 & 0,92 & 0,95 & 0,98 \\
\hline & VH & 0,84 & 0,88 & 0,92 & 0,96 \\
\hline \multirow[t]{5}{*}{$4 / 2$ UD } & VL & 0,96 & 0,99 & 1,01 & 1,03 \\
\hline & $\mathrm{L}$ & 0,94 & 0,97 & 1,00 & 1,02 \\
\hline & M & 0,92 & 0,95 & 0,98 & 1,00 \\
\hline & $\mathrm{H}$ & 0,87 & 0,91 & 0,94 & 0,98 \\
\hline & VH & 0,80 & 0,86 & 0,90 & 0,95 \\
\hline $2 / 2$ UD & VL & 0,94 & 0,96 & 0,99 & 1,01 \\
\hline Atau & $\mathrm{L}$ & 0,92 & 0,94 & 0,97 & 1,00 \\
\hline jalan & M & 0,89 & 0,92 & 0,95 & 0,98 \\
\hline satu & $\mathrm{H}$ & 0,82 & 0,86 & 0,90 & 0,95 \\
\hline arah & VH & 0,73 & 0,79 & 0,85 & 0,91 \\
\hline
\end{tabular}

Dengan demikian, 2 lajur dari 4 lajur (dengan pembatas median) Jalan Raya Kalirungkut yang merupakan akses utama keluar-masuk pusat perbelanjaan Transmart Rungkut dengan kelas hambatan samping tergolong sedang $($ High $)$ dengan lebar bahu jalan 1,5 maka nilai $\mathrm{FC}_{\mathrm{SF}}$ adalah 0,92

$\mathrm{FC}_{\mathrm{SF}}=\mathbf{0 , 9 2}$

e. Faktor koreksi kapasitas akibat ukuran kota (jumlah penduduk) ( $\left.\mathrm{FC}_{\mathrm{CS}}\right)$

Tabel 6.

Faktor koreksi kapasitas akibat ukuran kota (jumlah penduduk) $\left(\mathrm{FC}_{\mathrm{CS}}\right)$

\begin{tabular}{cc}
\hline \hline $\begin{array}{c}\text { Ukuran kota } \\
\text { (juta penduduk) }\end{array}$ & $\begin{array}{c}\text { Faktor penyesuaian untuk ukuran } \\
\text { kota }\left(\mathrm{FC}_{\mathrm{cs}}\right)\end{array}$ \\
\hline$<0,1$ & 0,86 \\
$0,1-0,5$ & 0,90 \\
$0,5-1,0$ & 0,94 \\
$1,0-3,0$ & 1,00 \\
$>3$ & 1,04 \\
\hline \hline Sumber: $\mathrm{IHCM}(1997)$ &
\end{tabular}


Jalan Raya Kalirungkut merupakan salah satu jalan Arteri Sekunder yang terletak di Kota Surabaya, dan berdasarkan data pada dokumen Kota Surabaya dalam angka tahun 2017, tercatat bahwa jumlah penduduk kota surabaya tahun 2016 tercatat sebanyak 3.016.653 jiwa yang menandakan bahwa ukuran kota dari Kota Surabaya adalah $>3$ juta penduduk dan nilai $\mathrm{FC}_{\mathrm{CS}}$ adalah 1,04.

$\mathrm{FC}_{\mathrm{CS}}=\mathbf{1 , 0 4}$

Berdasarkan perhitungan masing-masing variabel yang telah dilakukan diatas maka dapat diketahui kapasitas Jalan Raya Kalirungkut (2 lajur) yang menjadi akses utama kegiatan keluar-masuk pusat perbelanjaan Transart Rungkut Kota Surabaya, sebagai berikut:

Diketahui:

Tabel 7.

Faktor-Faktor Koreksi Tingkat Pelayanan Jalan Raya Kalirungkut

\begin{tabular}{ccccc}
\hline \hline $\mathbf{C}_{\mathbf{0}}$ & $\mathbf{F C}_{\mathbf{W}}$ & $\mathbf{F C}_{\mathbf{S P}}$ & $\mathbf{F C}_{\mathbf{S F}}$ & $\mathbf{F C}_{\mathbf{C S}}$ \\
\hline 3300 & 0,92 & 1,00 & 0,92 & 1,04 \\
\hline \hline
\end{tabular}

$\mathrm{C}=\mathrm{C}_{0} \times \mathrm{FC}_{\mathrm{W}} \times \mathrm{FC}_{\mathrm{SP}} \times \mathrm{FC}_{\mathrm{SF}} \times \mathrm{FC}_{\mathrm{CS}}(\mathrm{smp} / \mathrm{jam})$

$\mathrm{C}=(1650 \times 2) \times 0,92 \times 1,00 \times 0,92 \times 1,04$

$\mathrm{C}=2904,85 \mathrm{smp} / \mathrm{jam}$

2. Volume Lalu Lintas

Volume lalu lintas Jalan Raya Kalirungkut yang diperoleh melalui survei primer dengan cara Traffic Counting. Traffic Counting terhadap Jalan Raya Kalirungkut dilakukan pada 2 (dua) titik yaitu utara (sebelum pusat perbelanjaan Transmart Rungkut) dan selatan (sesudah pusat perbelanjaan Transmart Rungkut) selama 4 hari yaitu pada hari senin, selasa, sabtu, dan minggu (dua hari weekdays dan dua hari weekend). Waktu pelaksanaan Traffic Counting per harinya dibagi atas tiga range waktu yaitu $10.00-12.00,13.00-16.00$, serta $18.00-21.00$. Traffic Counting pada range waktu yang telah ditentukan adalah untuk mengetahui jam puncak (peak hour) kendaraan melintasi Jalan Raya Kalirungkut serta Pusat Perbelanjaan Transmart Rungkut Menarik pengunjung. Berdasarkan data jumlah kendaraan yang melintas di Jalan Raya Kalirungkut tersebut, diperoleh volume lalu lintas pada satu satuan waktu. Berikut merupakan hasil tabulasi perhitungan serta gravik volume lalu lintas di jalan Raya Kalirungkut:

Tabel 8.

Volume Lalu Lintas (Utara)

\begin{tabular}{ccccc}
\hline \hline Waktu & Sabtu & Minggu & Senin & Selasa \\
\hline $10.00-11.00$ & 1455,5 & 1334 & 1687,2 & 1510,9 \\
$11.00-12.00$ & 1636 & 1572,6 & 1614,2 & 1674,9 \\
$13.00-14.00$ & 1825,8 & 1478,7 & 1949,6 & 1964,9 \\
$14.00-15.00$ & 1818,9 & 1524,9 & 2204 & 2235,9 \\
$15.00-16.00$ & 1904,6 & 1523,6 & 2008,5 & 1994,5 \\
$18.00-19.00$ & 1558,4 & 1512,2 & 2237,2 & 2267,7 \\
$19.00-20.00$ & 1445,9 & 1648,4 & 1841,1 & 1828,4 \\
$20.00-21.00$ & 1586,4 & 1391,7 & 1540,4 & 1506,5 \\
\hline \hline
\end{tabular}

Tabel 9.

Volume Lalu Lintas (Selatan)

\begin{tabular}{ccccc}
\hline \hline Waktu & Sabtu & Minggu & Senin & Selasa \\
\hline $10.00-11.00$ & 1321,3 & 1205,5 & 1588,4 & 1321,3 \\
$11.00-12.00$ & 1542,7 & 1374,5 & 1541,2 & 1542,7 \\
$13.00-14.00$ & 1719,7 & 1380,1 & 1899,3 & 1870,2 \\
$14.00-15.00$ & 1763 & 1547 & 2167,8 & 2210,9 \\
$15.00-16.00$ & 1860 & 1554,4 & 1977 & 2071,4 \\
$18.00-19.00$ & 1485 & 1490,4 & 2193,2 & 2167,6 \\
$19.00-20.00$ & 1420,1 & 1609,1 & 1789,3 & 1794,2 \\
$20.00-21.00$ & 1581,9 & 1554 & 1652,6 & 1584,2 \\
\hline \hline
\end{tabular}

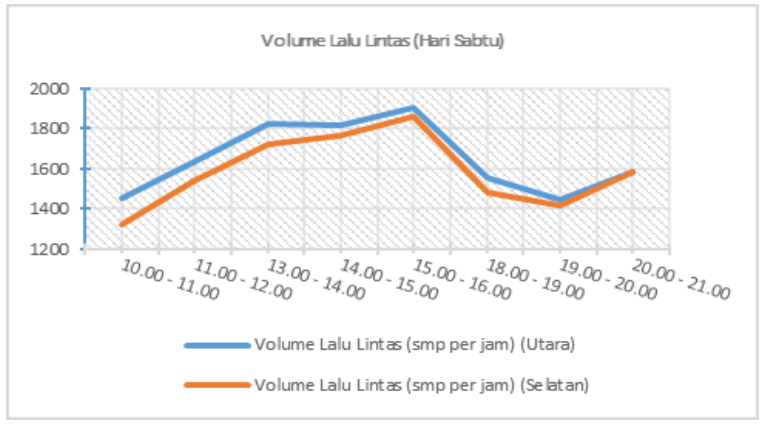

Gambar 2. Volume Lalu Lintas Pada Hari Sabtu (Weekend).

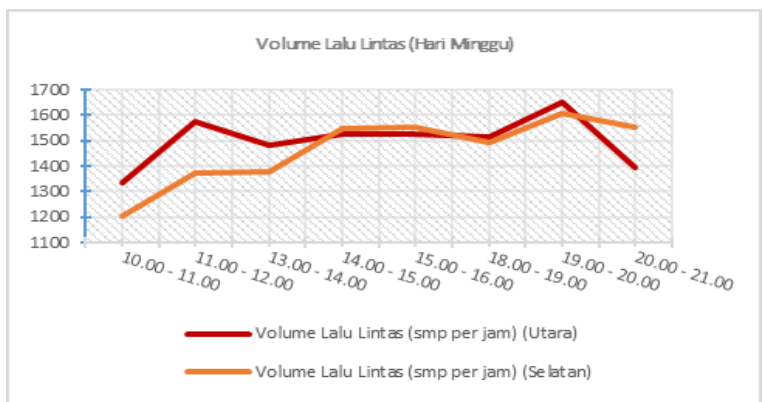

Gambar 3. Volume Lalu Lintas Pada Hari Minggu (Weekend).

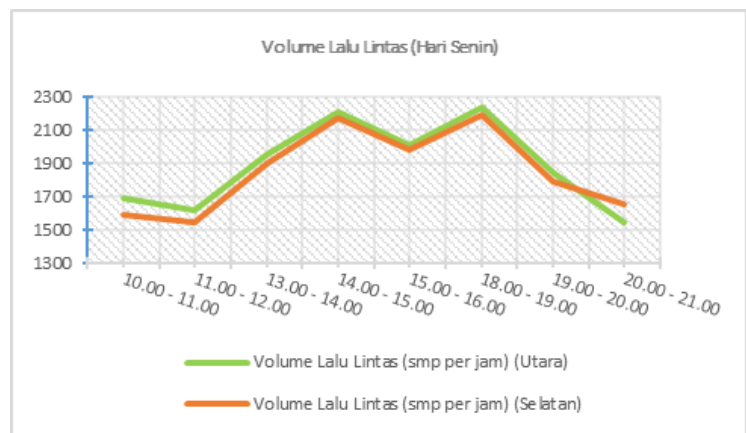

Gambar 4. Volume Lalu Lintas Pada Hari Senin (Weekdays).

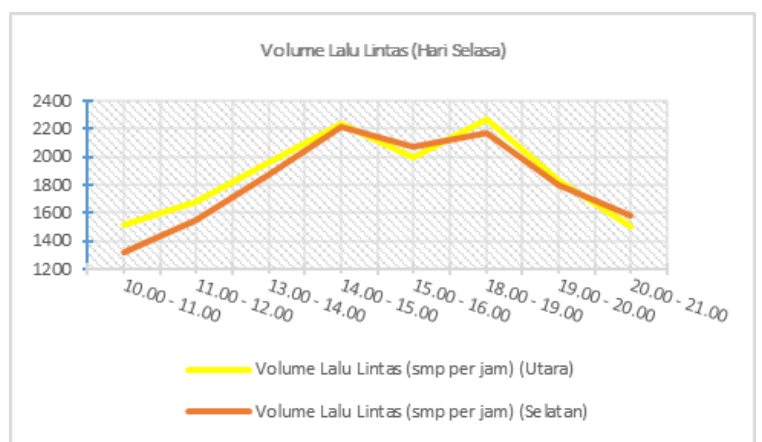

Gambar 5. Volume Lalu Lintas Pada Hari Selasa (Weekdays).

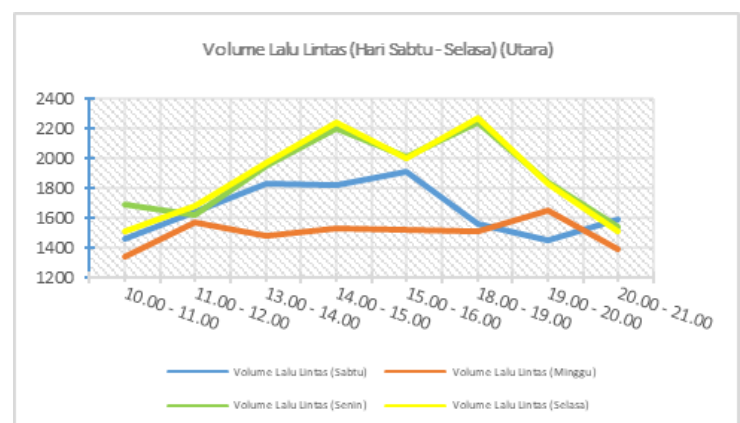

Gambar 6. Perbandingan Volume Lalu Lintas (Sabtu-Selasa) (Utara). 


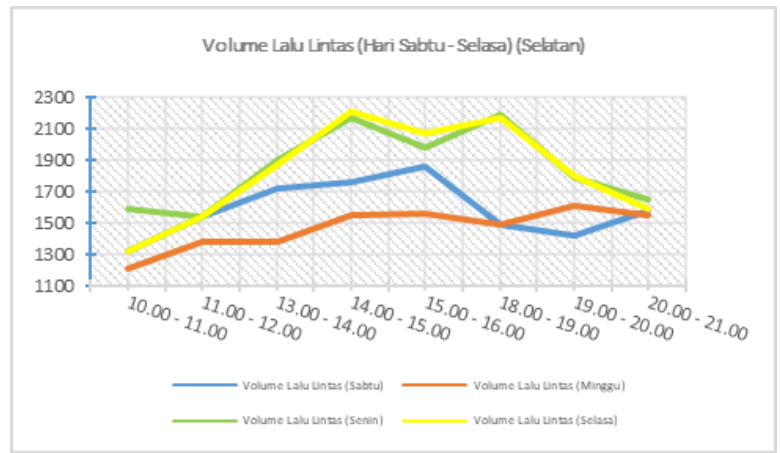

Gambar 7. Perbandingan Volume Lalu Lintas (Sabtu-Selasa) (Selatan).

\section{Analisa Tingkat Pelayanan Jalan}

Berdasarkan data kapasitas jalan dan volume lalu lintas yang telah diperoleh, dapat dilakukan analisa tingkat pelayanan jalanmenggunakan rumus kapasitas jalan, sebagai berikut:

$$
I=\frac{V}{C}
$$

Keterangan:

I = Intensitas Kinerja/Tingkat Pelayanan Jalan

$\mathrm{V} \quad=$ Volume Lalu Lintas (smp/jam)

$\mathrm{C} \quad=$ Kapasitas Jalan (smp/jam)

Berikut merupakan salah satu contoh penerapan perhitungan menggunakan rumus perhitungan tingkat Kinerja Jalan yang diterapkan pada salah satu waktu (senin, pukul 14.00 - 15.00):

$$
I=\frac{V}{C}=\frac{2204}{2904,6}=0,759
$$

Dan kemudian diperoleh hasil perhitungan kinerja jalan, sebagai berikut:

Diketahui:

Tabel 10.

Klasifikasi Tingkat Pelayanan Jalan

\begin{tabular}{clc}
\hline \hline $\begin{array}{c}\text { Tingkat } \\
\text { Pelayanan }\end{array}$ & Keadaan Arus Lalu Lintas & V/C \\
\hline \multirow{2}{*}{ A } & Kondisi arus lalu lintas dengan kecepatan tinggi & $0,00-$ \\
& dan volume lalu lintas rendah & 0.20 \\
B & Arus stabil, tetapi kecepatan operasi mulai & $0,20-$ \\
& dibatasi oleh kondisi lalu lintas & 0.44 \\
C & Arus stabil, tetapi kecepatan dan gerak kendaraan & $0,45-$ \\
& dikendalikan & 0.74 \\
D & Arus mendekati stabil, kecepatan masih dapat & $0,75-$ \\
& dikendalikan & 0.84 \\
E & Arus tidak stabil kecepatan terkadang terhenti, & $0,85-$ \\
& permintaan sudah mendekati kapasitas & 1.00 \\
F & Arus dipaksakan, kecepatan rendah, volume & $\geq 1.00$ \\
\hline \hline
\end{tabular}

Sumber: Traffic Planning and Engineering, and Edition Pergamon Press Oxword (1979)

Tabel 11.

Tingkat Pelayanan Jalan Raya Kalirungkut (Utara)

\begin{tabular}{ccccc}
\hline \hline \multirow{2}{*}{ Waktu } & Sabtu & Minggu & Senin & Selasa \\
\cline { 2 - 5 } & $\begin{array}{c}\text { LOS } \\
\text { (Kategori) }\end{array}$ & $\begin{array}{c}\text { LOS } \\
\text { (Kategori) }\end{array}$ & $\begin{array}{c}\text { LOS } \\
\text { (Kategori) }\end{array}$ & $\begin{array}{c}\text { LOS } \\
\text { (Kategori) }\end{array}$ \\
\hline $10.00-11.00$ & $0,501(C)$ & $0,459(C)$ & $0,581(C)$ & $0,520(C)$ \\
$11.00-12.00$ & $0,563(C)$ & $0,541(C)$ & $0,556(C)$ & $0,577(C)$ \\
$13.00-14.00$ & $0,629(C)$ & $0,509(C)$ & $0,671(C)$ & $0,676(C)$ \\
$14.00-15.00$ & $0,626(C)$ & $0,525(C)$ & $0,759(D)$ & $0,770(D)$ \\
$15.00-16.00$ & $0,656(C)$ & $0,525(C)$ & $0,691(C)$ & $0,687(C)$ \\
$18.00-19.00$ & $0,536(C)$ & $0,521(C)$ & $0,770(D)$ & $0,781(D)$ \\
$19.00-20.00$ & $0,498(C)$ & $0,567(C)$ & $0,634(C)$ & $0,629(C)$ \\
$20.00-21.00$ & $0,546(C)$ & $0,479(C)$ & $0,530(C)$ & $0,519(C)$ \\
\hline \hline
\end{tabular}

Tabel 12.

Tingkat Pelayanan Jalan Raya Kalirungkut (Selatan)

\begin{tabular}{ccccc}
\hline \hline \multirow{2}{*}{ Waktu } & Sabtu & Minggu & Senin & Selasa \\
\cline { 2 - 5 } & $\begin{array}{c}\text { LOS } \\
\text { (Kategori) }\end{array}$ & $\begin{array}{c}\text { LOS } \\
\text { (Kategori) }\end{array}$ & $\begin{array}{c}\text { LOS } \\
\text { (Kategori) }\end{array}$ & $\begin{array}{c}\text { LOS } \\
\text { (Kategori) }\end{array}$ \\
\hline $10.00-11.00$ & $0,455(C)$ & $0,415(B)$ & $0,547(C)$ & $0,455(C)$ \\
$11.00-12.00$ & $0,531(C)$ & $0,473(C)$ & $0,531(C)$ & $0,531(C)$ \\
$13.00-14.00$ & $0,592(C)$ & $0,475(C)$ & $0,654(C)$ & $0,644(C)$ \\
$14.00-15.00$ & $0,607(C)$ & $0,533(C)$ & $0,746(C)$ & $0,761(D)$ \\
$15.00-16.00$ & $0,640(C)$ & $0,535(C)$ & $0,681(C)$ & $0,713(C)$ \\
$18.00-19.00$ & $0,511(C)$ & $0,513(C)$ & $0,755(D)$ & $0,746(D)$ \\
$19.00-20.00$ & $0,489(C)$ & $0,554(C)$ & $0,616(C)$ & $0,618(C)$ \\
$20.00-21.00$ & $0,545(C)$ & $0,535(C)$ & $0,569(C)$ & $0,545(C)$ \\
\hline \hline
\end{tabular}

Berdasarkan hasil analisis tingkat pelayanan jalan pada kedua titik (utara dan selatan), diketahui terjadi fluktuasi naikturunnya tingkat pelayanan jalan yang diketahui dengan menghitung selisihnya $\left(I_{\text {utara }}-I_{\text {selatan }}\right)$, sebagai berikut:

Tabel 13.

Selisih Tingkat Pelayanan Jalan Raya Kalirungkut (Utara-Selatan)

\begin{tabular}{ccccc}
\hline \hline \multirow{3}{*}{ Waktu } & Sabtu & Minggu & Senin & Selasa \\
\cline { 2 - 5 } & $\begin{array}{c}\text { Selisih } \\
\text { LOS }\end{array}$ & $\begin{array}{c}\text { Selisih } \\
\text { LOS }\end{array}$ & $\begin{array}{c}\text { Selisih } \\
\text { LOS }\end{array}$ & $\begin{array}{c}\text { Selisih } \\
\text { LOS }\end{array}$ \\
\hline $10.00-11.00$ & 0,046 & 0,044 & 0,034 & 0,065 \\
$11.00-12.00$ & 0,032 & 0,068 & 0,025 & 0,046 \\
$13.00-14.00$ & 0,037 & 0,034 & 0,017 & 0,033 \\
$14.00-15.00$ & 0,019 & $-0,008$ & 0,012 & 0,009 \\
$15.00-16.00$ & 0,015 & $-0,011$ & 0,011 & $-0,026$ \\
$18.00-19.00$ & 0,025 & 0,008 & 0,015 & 0,034 \\
$19.00-20.00$ & 0,009 & 0,014 & 0,018 & 0,012 \\
$20.00-21.00$ & 0,002 & $-0,056$ & $-0,039$ & $-0,027$ \\
\hline \hline
\end{tabular}

Volume Lalu Lintas (Hari Sabtu-Selasa) (Selatan)

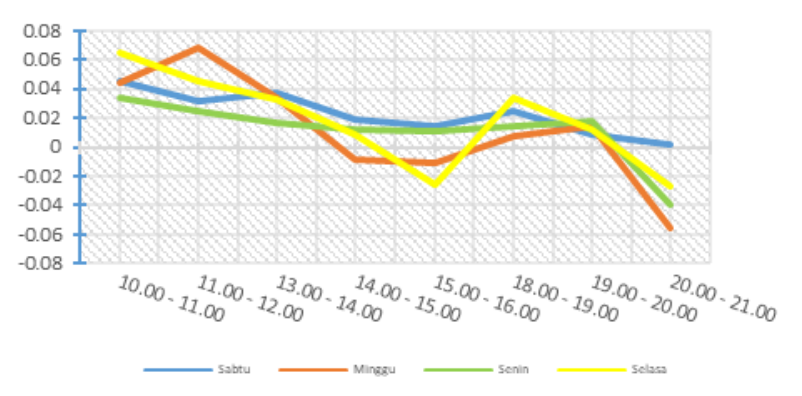

Gambar 8. Selisih Tingkat Pelayanan Jalan (Sabtu-Selasa).

Berdasarkan hasil diatas, diketahui bahwa hasil dengan nilai positif (+) merupakan keadaan dimana terjadi penurunan pada tingkat pelayanan jalan yang memiliki perbandingan yang sama dengan penurunan besar angka volume lalu lintas. Penurunan tersebut terjadi karena sebagian dari volume lalu lintas yang berkurang memiliki kepentingan di pusat perbelanjaan Transmart Rungkut, Sedangkan hasil dengan nilai negatif (-) merupakan keadaan dimana terjadi peningkatan pada tingkat pelayanan jalan yang memiliki perbandingan yang sama dengan peningkatan besar angka volume lalu lintas. Peningkatanan tersebut terjadi karena pengunjung pusat perbelanjaan Transmart Rungkut meniggalkan pusat perbelanjaan Transmart Rungkut.

\section{KESIMPULAN}

Jalan Raya Kalirungkut memiliki kapasitas sebesar 2904,85 smp/jam untuk 2 lajur yang menjadi akses utama keluar masuk kendaraan Transmart Rungkut Kota Surabaya. Berdasarkan hasil analisa perhitungan tingkat kinerja jalan diatas diketahui 
bahwa kepadatan lalu lintas terjadi di hari kerja (weekdays) khususnya pada jam 13.00 hingga 20.00. Serta, pada hari libur (weekend) dimana pengunjung Transmart Rungkut tergolong ramai kepadatan lalu lintas terjadi pada jam 13.00 hingga 16.00. Kedua waktu tersebut merupakan kondisi dimana Pusat Perbelanjaan Transmart Rungkut sedang beroperasi. Hal tersebut berdampak pada menurunnya tingkat pelayanan hingga pada kategori "C" yang berarti kondisi arus stabil dengan kecepatan terbatas, serta hambatan dari kendaraan lain semakin besar dan kategori "D" yang berarti Arus mendekati tidak stabil, kecepatan masih dikendalikan V/C masih dapat ditolerir.

Jalan Raya Kalirungkut untuk 2 lajur yang menjadi akses utama keluar masuk kendaraan Transmart Rungkut Kota Surabaya, diketahui bahwa hasil dengan nilai positif (+) merupakan keadaan dimana terjadi penurunan pada tingkat pelayanan jalan yang memiliki perbandingan yang sama dengan penurunan besar angka volume lalu lintas. Penurunan tersebut terjadi karena sebagian dari volume lalu lintas yang berkurang memiliki kepentingan di pusat perbelanjaan Transmart Rungkut, Sedangkan hasil dengan nilai negatif (-) merupakan keadaan dimana terjadi peningkatan pada tingkat pelayanan jalan yang memiliki perbandingan yang sama dengan peningkatan besar angka volume lalu lintas. Peningkatanan tersebut terjadi karena pengunjung pusat perbelanjaan Transmart Rungkut meniggalkan pusat perbelanjaan Transmart Rungkut.

\section{DAFTAR PUSTAKA}

[1] F. Miro, Pengantar Sistem Transportasi. Jakarta, 2012.

[2] O. Z. Tamin, Perencanaan dan Pemodelan Transportasi, 2nd ed. Bandung: Institut Teknologi Bandung, 2000.

[3] J. Noor, Metodologi Penelitian. Jakarta: Kencana Prenada Media Group, 2011.

[4] Sardjito, “Transportasi I," Surabaya, 2013. 